\title{
Von Willebrand disease type 2A
}

INSERM

\section{Source}

INSERM. (1999). Orphanet: an online rare disease and orphan drug data base. Von

Willebrand disease type 2A. ORPHA:166084

Type 2A von Willebrand disease (type 2A VWD) is a subtype of type 2 VWD (see this term) characterized by a bleeding disorder associated with a decrease in the affinity of the Willebrand factor (von Willebrand factor; VWF) for platelets and the subendothelium caused by a deficiency of high molecular weight VWF multimers. 